\title{
The hidden curriculum of work in English language education
}

\author{
Neoliberalism and early English programs in \\ public schooling
}

Peter Sayer

The Ohio State University

There has been a rapid global expansion of English instruction in the early grades in public school curricula. Particularly in so-called developing countries, the increase of and its shift from exclusively private to public education is linked to the idea that acquiring English promotes personal, social, and economic development. The author takes one case of a recent early English program, the national program in Mexico, and argues that it is a representative case of a language education programme and policy organized around neoliberal principles. The policy's stated goal is to address issues of access and equity for public school students; however, findings indicate that the actual processes of teaching and learning at the classroom level remain highly stratified across social class lines. An analysis of English lessons in schools at different points on the socioeconomic spectrum illustrates that instruction is preparing children with certain types of skills and dispositions congruent to their class position and revealing the hidden curriculum of work in early English education.

Keywords: English for young learners, Mexico, hidden curriculum, social class and language pedagogy, neoliberalism, human capital

English is not so much a language as a discursive field: English is neoliberalism, English is globalisation, English is human capital.

(Pennycook, 2007, p.112)

\section{Introduction}

Internationally, English education has expanded rapidly during recent years in public primary schools (Enever, 2012). The principle rationale for the creation of these early English programmes is that, in the new era of globalization, proficiency 
in English gives individuals greater social and economic opportunities. Especially in so-called developing countries, knowing English is discursively linked to global competitiveness and modernization (Bruthiaux, 2002; Vavrus, 2002). Often the need for learning English is taken as self-evident. Particularly in poorer countries, parents often have a strong preference for early English and English medium programmes (Billings, 2014; Kuchah, 2018). Whereas many countries have traditionally relied on a model of elite bilingualism (de Mejía, 2002), where meaningful opportunities for English acquisition was limited to a relatively small number of students attending private schools, the growth of public programmes signals move towards policies that promote "English for everyone" (Wedell, 2008). On the surface, the opening of access to English instruction to all students and starting from the primary grades seems to be a move towards greater educational and linguistic equity.

In many countries, however, introducing a large-scale English programme in public education is complicated and expensive. Research on early English programmes in developing nations has identified numerous challenges of implementing, top-down, large-scale programmes within education systems with weak infrastructures, such as in Latin America (de Mejía, 2009; Matear, 2008; Ramírez, Sayer, \& Pamplón Irigoyen, 2014) and Southeast Asia (Clayton, 2006; Hamid, 2010; Nguyen, 2011). Zentz (2016) explains that in Indonesia:

The state is in a double bind [...]: in globalization, English cannot be avoided, but the state lacks the resources needed to meet internationalized standards with language and curriculum content appropriate to the needs of Indonesia's student populations and the skills of its teachers. Because of these dynamics, the English language is accessed mostly by those who already have access to mobility, wealth, and 'international standard' educations.

Nevertheless, despite the significant resources it takes to implement a programme, the strain it can place on an underfunded public education system and the dubious learning outcomes that many programmes produce, the costs are seen as justified, if only because other countries are moving ahead quickly with English and, after all, one does not want to be left behind. Wedell (2013) argues that policymakers are likely guided more by parental and societal pressures than by any actual evidence of the link between English proficiency and real socioeconomic opportunities.

In this article, I will interrogate the premise of the expansion of public early English through the lens of the programme in Mexico. In many ways, Mexico is a prototypical case. Historically, children in private schools studied English in early grades, and public schools started English in secondary school (about grade seven) (Sayer \& López-Gopar, 2015). In 2009, the Ministry of Education 
launched the National English Programme for Basic Education, now called the Programa Nacional de Inglés (PRONI). This lowered the start of English to kindergarten, effectively expanding English instruction from three to ten years. It also came with a massive concomitant investment in hiring and training almost 100,000 new English teachers for 17.2 million children ages 5-12. The case of the Mexican programme, I will argue, represents a central problem with public early English programs: they have failed to take into account how schools and classrooms are structured by the dynamics of social class. Curriculum developers and language education policymakers have not addressed how exactly these English programmes actually generate greater socioeconomic opportunities in real terms.

Drawing on earlier critical theorists' examinations of class, education, and social reproduction (Bowles \& Gintis, 1976) as well as recent work in applied linguistics on language and social class (Block, 2014), I examine how English instruction differs in classrooms across social classes, what Anyon (1981) referred to as the hidden curriculum of work. The findings indicate that new early English programmes do little to disrupt the social order of schooling, and that pedagogical practices in L2 English classrooms remain yoked to teachers' class positioning of students, suggesting that the inclusion of English in early grades in public schools does not, in and of itself, change the underlying educational processes that remain heavily stratified along class lines. Moreover, the types of differentiated processes documented across social class support the notion that the hidden curriculum of early English programmes for public schools aligns with the interests of neoliberal education policies (cf. Block, Gray, \& Holborow, 2012; Park \& Wee, 2012).

I begin with an explanation of the methodology, and a description of English lessons in three types of schools: a private, English-medium school, an uppermiddle class public school, and a working-class public school. I then analyse the lessons through the concept of the hidden curriculum and connect the pedagogical approach in each lesson to the social class dynamics of the school. The alignment of the language lessons to the students' social class positions reveals the ways that the organization of early English programmes has been influenced by the notion of language learning as the development of human capital, reflecting broader neoliberal pressures. Finally, I consider the implications for teacher preparation. I argue that, besides emphasizing strong oral language skills and knowledge of effective L2 teaching methods, the knowledge base for English for young learner (EYL) teachers should include preparation for working in public schools. An important facet of this preparation entails building critical pedagogical awareness of how teachers can tacitly reinforce or intentionally disrupt class-based differences in their classrooms. 


\section{Methodology: An impact study of the early English programme in Mexican public schools}

The study is organized as a comparative case study. An explicitly comparative approach to case study research "is particularly well-suited to [...] consider how social actors, with diverse motives, intentions, and levels of influence, work in tandem with and/or in response to social forces to routinely produce the social and cultural worlds in which they live" (Bartlett \& Vavrus, 2017, p.1). It follows Anyon (1981) in providing descriptive accounts of classrooms using an explicitly social class comparison based on the detailed observation of pedagogical practices of teachers in focal schools, triangulated with interviews with teachers and students. It builds from a previous analysis of class-based pedagogies in English lessons in sixth-grade public school classrooms (Sayer, 2018). As in Anyon (1981), the three focal schools are chosen to represent particular points across the socioeconomic spectrum, and the same terminology is adopted to identify the working class, middle class, and affluent schools. ${ }^{1}$ Bartlett and Vavrus (2017) term this approach a horizontal comparison of homologous cases. The portraits of the three schools below are based on a series of projects carried out from 2009-2017 with English teachers in over 40 schools across five different states, covering most of the geographical areas across the country. The description of each school is presented as typical cases according to the average socioeconomic level of the parents and of the neighbourhood where the schools are located. The portraits were developed as a composite view of representative conditions and practices gleaned from extensive classroom observations, interviews with teachers, students, principals, and parents, and documented with fieldnotes, observation protocols, photographs, and audio and video recordings. The research team consisted of four researchers and a videographer, who observed at least four English lessons with different teachers across grade levels, and conducted at least seven interviews (and focal group interviews in the case of the students and parents) of key stakeholders, depending on the size of the school and number of English teachers.

The specific analysis of class differences in public schools and the photographs included here are taken from a project during 2014-15 in one central Mexican state where the national English programme had been implemented sev-

1. Anyon (1981) also studied an "executive elite school", at the top $1 \%$, which was not part of the dataset in this study. Also, she termed her upper-class school "affluent professional." I labeled this school simply "affluent", because many of the types of employment we associate with the professional class, such as teachers, nurses, and dentists, are squarely middle-class jobs in Mexico. 
eral years prior. It included a representative sample of 15 primary schools, grades 1-6. The classifications of schools according to social class was based from an "SES-level" (socioeconomic status level) designation assigned by the State Ministry of Education, based on demographic data of the average income of the neighbourhood in which the school is located, and verified by myself and the research team through observations and the principal interview during the site visit, visually by looking at the material conditions of the school and by asking the students ${ }^{2}$ about their parents' occupations and access to certain types of resources indicative of material and cultural capital (e.g. internet access at home, travel abroad). The general characterizations of school type listed at the end of each description were compiled from across the dataset using NVivo, a qualitative software program to code the observations for particular instructional strategies and practices with the school's SES-level designation. For each type of school, the descriptions below focus on lessons in third grade (ages 8-9) in order to give a common point of comparison.

The description of the private school is based on observations done during a teacher professional development project carried out in southern Mexico during 2017, as well as my prior work as an English teacher trainer observing practicum teachers in Mexico over many years. In fact, my memories of my earlier observations of student-teachers assigned to do their practicum in private schools was instrumental in helping me become aware of how English teachers had to confront social class differences. It should be noted then the dataset that the private school description is based on is much smaller, and the data were collected less systematically. Moreover, there is more variation in the way English is taught in private schools, and the description here is therefore not representative of all private schools. For example, some middle-class private schools where English is taught as a foreign-language subject are more similar to the description of the middle-class public school. The affluent school described here is on the upper end of the socioeconomic spectrum. It is not one of the very elite schools, but parents are successful merchants or business owners, or work in banking and finance.

The differentiation of the three types of schools is seen clearly in the income disparity between the students' families. Parents in the working-class group were

2. Focal group interviews were conducted with students in 5th and 6th grade, generally one group of three "high performing" students in English class, and one "average" group, as determined by scores on an English proficiency test and selected by the students' teacher. The students were invited to participate voluntarily, and were asked to describe what they liked and disliked about their English class, what if anything they did with English outside of school, and to confidentially "grade" their teacher. Most enjoyed English class relative to other subjects, though they were often quite candid in the assessment about what they did not like. 
mainly unskilled and semi-skilled laborers, or "blue-collar" hourly wage jobs such as tradespersons, shop clerks, manufacturing, and in the service industry. ${ }^{3}$ Parents in the middle-class school were professionals, such as teachers, nurses, and managers. Block (2014) emphasizes that social class is best understood as a set of relations, not as income levels; however, income does provide a solid comparative indicator of access to various forms of cultural capital. In Mexico, income levels are calculated based on the minimum salary, set by the government. In 2018 one minimum salary is equivalent to US\$92 per month (given as 88.36 Mexican pesos, or US $\$ 4.60$ per day). In general terms, the income levels for the three types of schools can be expressed in the following ranges, as well as the percentage of Mexicans across the country who would be considered within each range:

Table 1. Salary ranges for the types of schools ${ }^{*}$

\begin{tabular}{lccc}
\hline $\begin{array}{l}\text { Social class of } \\
\text { school }\end{array}$ & $\begin{array}{c}\text { Minimum salary } \\
\text { range }\end{array}$ & $\begin{array}{c}\text { Equivalent annual } \\
\text { income }\end{array}$ & $\begin{array}{c}\text { \% of the } \\
\text { population }\end{array}$ \\
\hline Working class & $<1-5$ min salaries & Up to US\$5500 & 60 \\
Middle class & $9-25$ & US\$10,000-25000 & 34 \\
Affluent & Above 40 & US\$45,000 & 5 \\
\hline
\end{tabular}

* Salary ranges and income figures adjusted to 2018 levels (Secretaria de Hacienda, 2018). Percentage of total population based on Forbes (2014), and the National Census Burea (INEGI, 2016).

The interviews with students also corroborated that income levels are related to opportunities to engage in social practices through English outside of school. While students in all schools reported listening to music, watching American movies, and playing video games in English, middle class children were much more likely to be playing the games through an internet connection, to be playing language-learning specific apps on a tablet, and to use English to resolve other sorts of real-world problems (such as watching a tutorial in English on YouTube to figure out how to defeat a monster in a video game). Affluent children reported either having already used English or planning to use English to travel to Englishspeaking countries to visit or study.

3. Only schools in urban/suburban areas are compared, since only a few of the schools were in rural areas, where families work in agriculture. However, the schools in the sample in rural areas were all classified as working class, so there was no point of comparison across social class levels. 


\section{How social class shapes English classrooms in Mexico: Three schools compared}

In this section, I present portraits of three schools. The descriptions include the physical spaces of each school, indicating the material resources at hand, as well as typical pedagogical practices of the English teachers at each school, representing how the educational processes of studying English in each educational context embody certain class-based social practices. I include excerpts from teacher interviews that illuminate their views on the school, the students, and their teaching. Although Mexico has a large income gap, and inequities in access to English have long been shaped by social class disparities (López-Gopar \& Sughrua, 2014), it is important to note that there are similarities across the three schools. All the schools teach the same subjects since they must be aligned to the national curriculum in order to be accredited (and none is a religious school or part of the parallel indigenous education system in Mexico). In third grade, this includes Spanish (language arts), mathematics, natural sciences, the geography and history of the local state, civics/ethics, physical education, arts, and English as an additional language.

The desks in all three classrooms are organized into rows, and the most common format for lessons is teacher-fronted instruction from the whiteboard, with students responding to questions chorally or individually from their seats, or sometimes being called to the front to fill in answers on the board. Whole group instruction is generally followed by small group work or individual seat work from the book. The public schools use the same, ministry-produced textbooks for all the subjects except English. This to say, all three schools conform to the grammar of schooling (Tyack \& Tobin, 1994), meaning "the regular structures and rules that organize the work of instruction. [F]or example, standardized organizational practices in dividing time and space, classifying students and allocating them to classrooms, and splintering knowledge into 'subjects'” (pp.453-454). Nevertheless, while the institutional organization is similar, the processes of teaching and learning are moulded by the social class position of the students.

\section{The working-class school}

The working-class school is a two-storey, concrete building with fading lime green paint arranged like most Mexicans schools in a U-shape around a central patio. The building is old but in relatively good shape, surrounded by walls and a chain-link fence topped with razor wire (see Figure 1). Most students come from the surrounding neighbourhood, the younger ones walking with mothers or older siblings, the older children walking in groups. The school is located in a suburban 
area, about 20 minutes by bus from the city centre and near the edge of a large industrial park. Many of the parents work in the warehouses and manufacturing at the industrial park, in the local shops and restaurants, in the neighbourhood, or at stores and offices downtown.

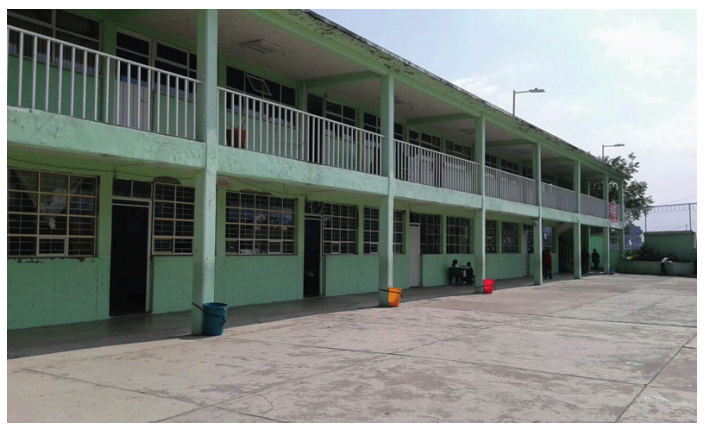

Figure 1. The working-class school

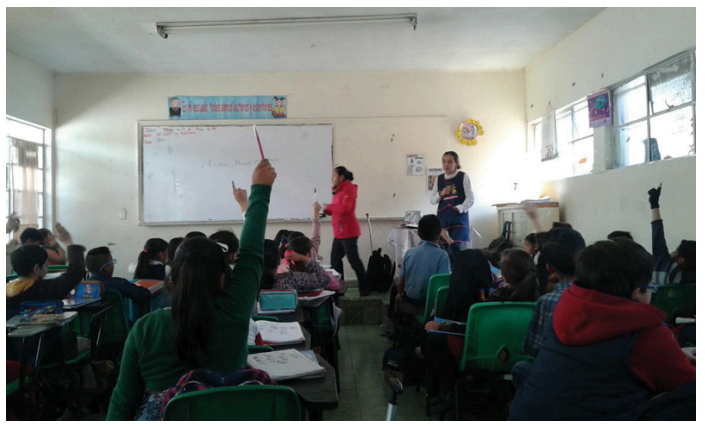

Figure 2. Classroom in the working-class school

The teachers and students

There are two English teachers at the school, one each for roughly half of the 18 classrooms, with a mix of groups from grades $1-6$. Each group is scheduled to receive three 50-minute lessons per week ( $2^{1 / 2}$ hours of instruction weekly), though in practice it is usually only one or two. The teachers rotate from one class to the next, dragging a small cart of materials behind them. The classes are large, about 40-45 students, and the rooms are crowded, and the sound of loud voices bounces from the concrete walls. The classroom teacher usually stays in the room to help the English teacher maintain discipline. The regular teacher often sits at her desk in the front marking papers and occasionally yelling out the names of students who get too noisy. This leaves the English teacher a very small rectangle of space at the front of the room to accommodate her materials and move around. 
The English teachers admit they cannot remember all their students' names; there are too many. Also, since few English teachers have permanent contracts, they are usually moved to new schools on a two-year rotation. One of the teachers explains that she arrived this year, having been rotated from a "nicer" school in a better neighbourhood.

Peter: What are the differences between this school and the previous one [you worked at last year]?

Teacher: The students at the other school were calmer. Here they are more rebellious. It's because of the environment we are in, which is a pretty rough neighbourhood. At my last school they were calmer, and there was more support from the parents. Here there really isn't much support from parents.

The other teacher also attributes classroom difficulties to lack of parental support, explaining that many parents have a "mentality" which makes them not appreciate the value of learning English:

Teacher: The thing is that, the parents' way of thinking - and really more so in situations of low resources - is that they are still reluctant to accept this subject [English]. If you ask why, it's because they want a sort of different kind of education, preparation, because of their level of resources. So they see English as something very distant to their situation. So if their child doesn't make an effort with the language, that's fine, it's not important. So that's the main barrier we face here, this mentality of the parents, where there's not much interest in helping with homework, with keeping an eye on the child's progress...

In interviews with parents, however, there was little evidence of a reluctance to have their children learn English attributed by the teacher. Instead, parents were by and large grateful that the children were now studying English, insisting that "English opens many doors." Some did complain that classes were too large to learn well and that the school had problems and expressed regret that they could not afford to send their children to extracurricular language classes so that they could learn to speak the language well.

\section{The lesson}

Many of the lessons observed in the working-class school bore out the parents' concerns and provided few chances to use English in a communicative sense. A typical lesson focused on vocabulary. After giving a lesson on vocabulary for clothing from the front of the classroom using picture flashcards, the students 
copy the words into their notebooks, write the translation of the word in Spanish, and sometimes draw small pictures to accompany the words (see Figure 3). Capital letters are written with a different colour ink. Students are quizzed on the meaning of particular words (e.g. What is this? [holding a picture of a vest]), and the memorization of isolated word lists is emphasized. Only very rarely are students asked to use the word in relation to a meaningful context or connecting to other kinds of social knowledge (e.g. What clothes should you wear to church? Or what clothes do women/men wear?) or to express personal opinion (e.g. what's your favourite piece of clothing? Or What clothes do you think are most comfortable?). When students do look at vocabulary in context, it often becomes a mechanical task. For example, during a lesson where students looked at important holidays during different months of the year, the teacher presented the example: In September we celebrate Independence Day. However, rather than discuss Mexican Independence Day and compare it with celebrations in English-speaking countries, the students were tasked with copying a list of the months of the year and ordering each month with an ordinal numeral (see Figure 4).

is the month of the year.

Because the desks are crowded close together, with backpacks spilling into the aisles, the teacher cannot circulate around the classroom, and it is difficult and time-consuming to change the configuration to rearrange for students to work in small groups. The teachers said they also have even more trouble maintaining control of the group when working in small groups, and the regular teachers become exasperated if the group becomes too unruly.

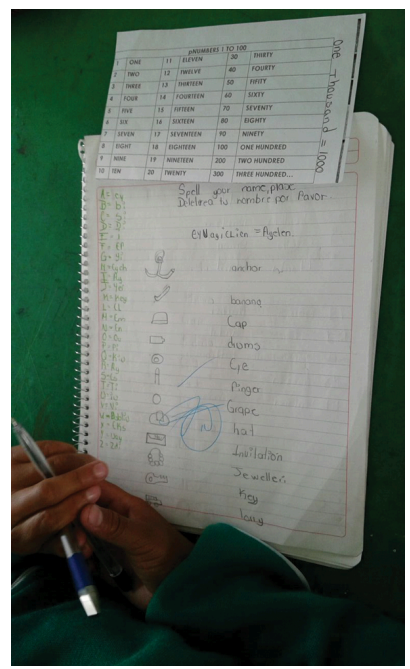

Figure 3. Copying a word list 


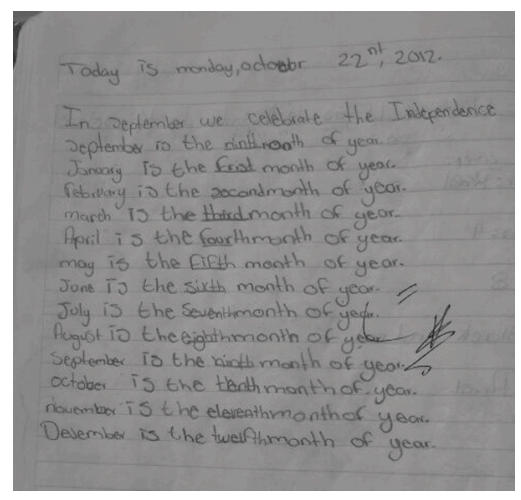

Figure 4. Copying sentences

Upon completing the task, students brought their notebooks to the teacher's desk. Full marks were given if the student spelled the month correctly and filled in the correct ordinal. Many of the students had already studied basic vocabulary: months, body parts, clothing, and jobs. When asked to explain the approach, the teacher explained that because students do not practice English outside the classroom, they often failed to learn basic vocabulary well, so it has to be repeated each year. This often prevents students from the working-class school from getting to the "advanced topics" they need by sixth grade, the end of primary schooling, because teachers are constantly having to recycle the same vocabulary and cover the same basic grammar rules.

Overall, the characteristics of lessons in the working-class school are:

- Whole group instruction on basic vocabulary and grammar. Students answer chorally, raise hands, or shout out answers.

- Students copying what the teacher has written on the board into their notebook.

- Emphasis is on correct spelling, and proper format, such as the use of colours to indicate capitalization.

- Word lists with translation. (see Figure 4)

- Use of grammatical knowledge to complete worksheets (e.g. fill in the blanks with the past tense of the verb).

- Focus on classroom procedures: how to behave, how to complete worksheets, fill in notebooks.

- Attention to working quickly and getting details completed accurately.

- Very large classes made alternative grouping difficult, and the perception of behaviour problems made teachers reluctant to do activities that would create noise and loss of control.

- Focus on producing the correct response; little to no evidence of students using the language producing their own meanings 
In the four working-class focal schools in the sample, 11 of the 16 observed lessons $(68.8 \%)$ had most of these characteristics noted here, and most of the lessons that did not were in grades 1-2; by fifth and sixth grade, almost all the lessons conformed to the general pedagogical approach described above.

The middle-class school

The middle-class school is in a suburban neighbourhood near the city centre filled with single-family homes. In the mornings, many children walk to school; others are dropped off by parents who drive or take the city bus. Since this school is recognized as a "good" public school, many parents from other parts of town use personal connections to get their children enrolled. The school is freshly painted, and the entranceway is filled with student-produced posters and projects, a large brightly coloured mural emphasizing the importance of taking care of the environment and not wasting water, and a portrait of a hero of the Mexico Revolution. The school is clean and has small green garden areas throughout.

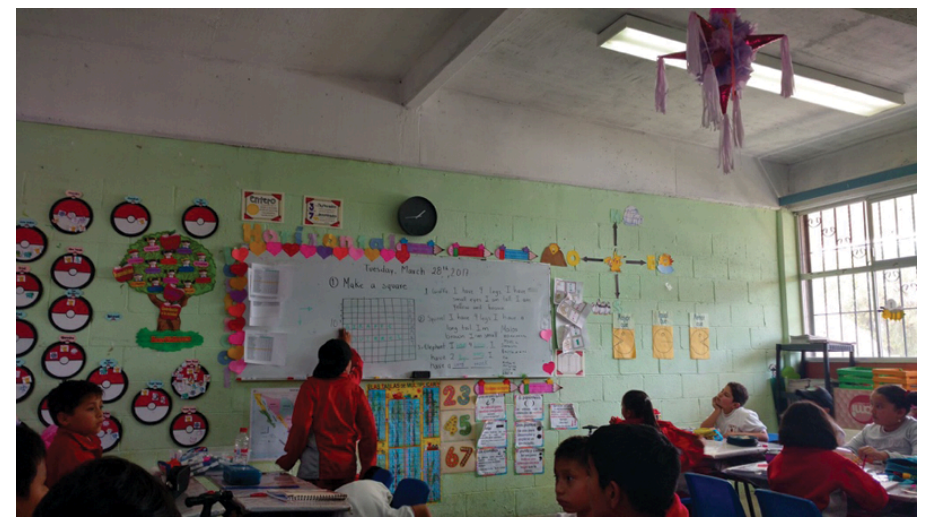

Figure 5. Classroom in the middle-class school

\section{The teachers and students}

The English teachers at the middle-class school also "teach off the cart," bringing their supplies from room to room. However, at this school, they have a small room next to the janitor's closet where they can store their materials, with a small table and desk to prepare the lessons. They have a portable CD-player they share. Almost all of the students have their own English textbooks, produced by commercial publishers but provided free through the Ministry, and each student pays a few pesos per month so the teacher can make copies and get supplemental materials. The school has a small computer lab, and the teachers are working with the 
principal to get some software in English so the students can have extra practice. The students also have three 50-minute English lessons per week. One teacher has started at the school this year, having been transferred from a working-class school, and explains:

Teacher: I have to say, it's like a tough crowd over there, it's a complicated situation but I think on a personal level the kids are very sweet, maybe not so motivated but very sweet. With these kids I have to pay attention to the affective side, to gain their trust and attention. [...] They are respectful and behave well, maybe they're not so sweet, but they work hard and they participate. They know that we expect they must make the effort. So overall maybe here it's easier too because the groups aren't so big. [nb: 25-30 students, versus $40+$ in many public schools]

\section{The lesson}

The teacher begins the third-grade lesson with a game of Simon Says as a warmup activity to review parts of the body. Then the students go out to the patio and roll large cardboard dice to indicate the activity they must perform. The teacher makes the game competitive by dividing the group into teams and keeping score. She explains the rules of the game in English while modelling the activity energetically so the children will understand what to do. "What is the name of your teams?” she asks. One group shouts out in English “Tigers!” Most pick animal names but one group of boys picks the name of an English football team with a famous Mexican player and the teacher accepts it.

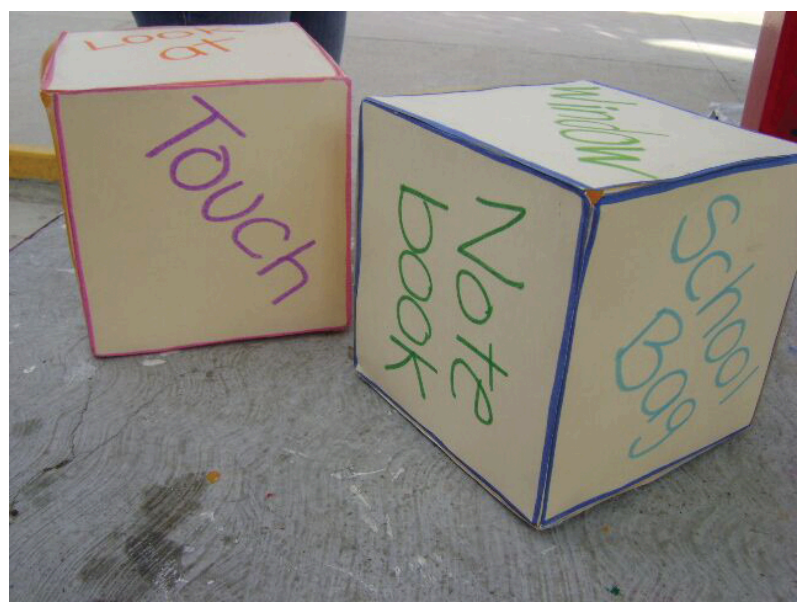

Figure 6. Playing a game in the patio with giant dice 
When the dice game ends, the teacher brings the group back inside. The regular classroom teacher has left, but the English teacher re-establishes order and asks the students to present their posters they have been working on. The posters list some sort of process involving technology: how to play a video game or use a YouTube tutorial. Most use fairly complex language but seem to have copied it from somewhere. The classroom is somewhat chaotic as some groups scramble to finish their posters, spreading out across the floor and tables. The teacher circulates and asks each group leader to read the poster aloud. The teacher does not correct the students' pronunciation but does encourage students (using Spanish) to read in a loud voice, although it is still difficult to hear because half the groups are watching the presentation while the others continue to work on their own posters. One group presents on a Sony PlayStation game; apparently, one of the students has the console at home and copied the instructions from the screen (see Figure 7). The handwriting is poor, but the teacher gives them a happy face because they presented well and made a detailed picture. She reminds them too that they were supposed to use the sequence words, First, Then, Next, After that, Last... She asks them to add the words and continues to the next group.

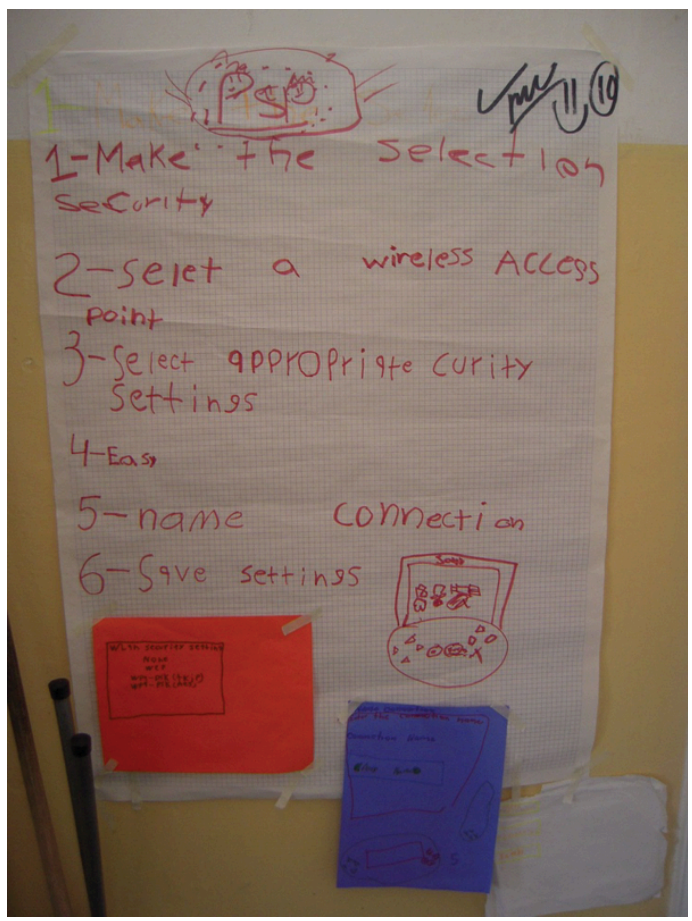

Figure 7. Students' projects 
English lessons at the middle-class school were characterized by:

- Predominantly whole group instruction, but usually at least one small group or kinaesthetic activity.

- Lessons often contain a "fun" element, such as games, often with some competition.

- Language usually presented with some communicative context, such as ordering sentences to form a story.

- Some evidence of building of intercultural awareness through the introduction of cultural content (e.g. students compare traditions of Halloween and Day of the Dead).

- Procedures are still emphasized, but students encouraged to use English to navigate procedures (e.g. asking the teacher in English "May I go to the bathroom?")

- Focus still tends to be on language forms (heavy emphasis still on vocabulary), but students have some opportunities to express opinions and produce work based on their own ideas.

- English presented as a foreign language but seen as something useful and relevant to students.

In the four middle-class focal schools in this sample, a total of 13 lessons were observed, and more than three-quarters $(76.9 \%)$ of the lessons observed had most of the characteristics noted here.

\section{The affluent school}

The affluent school is on a hill overlooking the city. In the mornings, children are dropped off in private cars, which pull in an orderly fashion through the front of the school that is set up with a covered entrance like a fancy hotel. There is a security guard at the front gate, and teachers arriving have to check in with their electronic name badge before being able to enter. Inside, the three-story school is laid out around a large central basketball court (see Figure 8). The playing surface is brightly coloured and made of some special rubberized material. The school is affiliated with one of the Catholic orders, and large vinyl banners promoting the school's values hang around the courtyard. Outside the English classroom, one of the older grades has made a poster for a fundraiser to help people affected by a serious flood in the neighbouring state of Veracruz. The teacher explains they will take the poster to the main plaza so that tourists will donate money, it will help the children learn social responsibility. 
The hidden curriculum of work in English language education

51

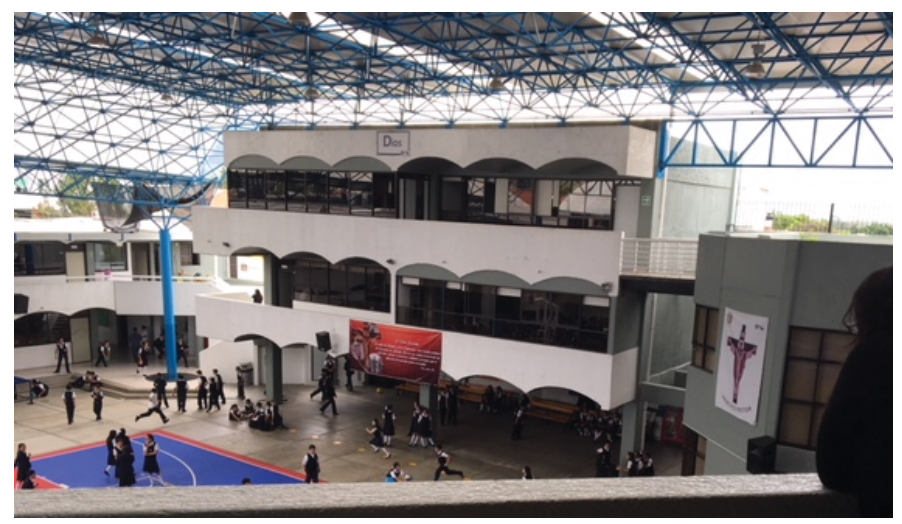

Figure 8. The courtyard of the affluent school

Veracruz Needs your Help! Veracruz was affected after two weeks of heavy rain. Thousands of houses are under water. More thar one million people lost their houses they are living in shelters. Many people need medical at food and shelter. The govern of Veracruz does not have en money to help everybody wi affected by the floods. National and International are distributing food.

Figure 9. Poster to help flood victims 


\section{The teachers and students}

There are several classrooms set up for English. The younger grades stay in their own room for English, but starting in third grade the students go to the dedicated English room. Here the teachers have decorated the rooms with brightly-coloured commercially-produced charts and posters. The school bills itself as "bilingual." Unlike the public schools, it does not use the national English programme; instead, it uses a content-language integrated learning (CLIL) approach, using English as the medium of instruction to study language arts, science, geography, and world history. The students use textbooks produced for the U.S. state of Texas, which the parents have to purchase at significant cost. Here the school day is almost two hours longer than in public schools, and students study in English two to three hours per day. One teacher who had completed his practicum in a public school said:

Teacher: So, it's pretty obvious the difference between this one and the public school, you can tell. For example, here there's just a whole range of tools, there's a bunch of good materials, I have the books, the audios, the videos, the computers, with internet connection, I've got my own classroom, the English classroom so I can put up whatever I like, charts and posters. I have all I need, and that's the big difference, because the students know they're coming into this context, the English classroom, and they're going to be hearing and using and learning it.

The teachers have similar training to their colleagues in public schools; most have come through the same programmes. Because they are expected to teach subjects through English, the teachers should have a higher level of spoken proficiency.

\section{The lesson}

During science period, the lesson is on light and refraction. The teacher begins by directing the students' attention to the book, and the text which explains the concept of refraction. The main academic vocabulary is written in boldface type and defined in a small box in the margin. He reads the text aloud slowly, translating a few unfamiliar words (the light bends as it passes through the glass), and then nominates a student to read the comprehension questions, and another student to answer. After a few minutes, he moves to the computer project and shows the students a short video called BrainPop, which presents the same concept. There is an on-line quiz at the end, which the teacher leads them through while students shout out the answers in English. The teacher teaches entirely in English, only infrequently switching to Spanish for classroom management. Both the textbook 
and the video have been produced for native speakers, but most of the students seem to be able to follow; it is unclear if they are understanding everything in English, or if they have already covered similar content in Spanish.

The teacher then brings out boxes with prisms, magnifying glasses, and lights. The students move their desks into a larger workstation (the desks are designed to be quickly reconfigured into a 4-seat table), and each table gets a box. One group decides to work on a mat on the floor. The students are given an activity sheet in English, a graphic organizer to record the information from their "experiment." The activity is to use light refraction to produce a rainbow, and then record the colours. They then have to change the pattern, making it longer or shorter, and observe and record what happens. The teacher circulates to help students, referring them back to the text to resolve doubts and using leading questions to get them to think through their answers: "Is this looonger, or shorter? [motions with hands] Here you put It is short, are you sure about that?"

The teacher said he feels comfortable teaching in English and has learned the content now through the book, but he said that initially, he was insecure about teaching academic subjects because he was not trained in content areas:

Teacher: So now I think I can do okay with this kind of lesson, I guess just by trial and error really. Because at first [when they said he would teach subjects in English] I thought "Wow, I'm not really good at science." Geography is okay, I like that subject, but I mean, [science] wasn't really my best subject, you know? And like this is only a third-grade class, and like ['refraction'] and a lot of the vocabulary is the same in Spanish and English, but in the beginning, I had to really learn it myself, because I wasn't so sure.

Despite the teacher's lack of familiarity with the specific content area knowledge, the students seem to engage with the lesson at a fairly high level, and though they speak Spanish mostly amongst themselves during the experiment, they are able to complete the work in English. In general, lessons at the affluent school can be described as:

- English used as the medium to access other forms of academic and scientific knowledge.

- Uses of English are integrated with other social practices, such as using the internet to find information.

- Teaching English is connected to developing critical thinking skills and independent decision-making.

- Intercultural awareness is assumed: many students in primary grades have travelled to English-speaking countries, and there is an assumption that students will interact with native English speakers. 
- English taught within a bilingual model, with materials geared towards native speakers.

\section{Outliers, teacher rotation, and teachers' social class}

An important side note which seemed to affect the functioning of the programme in the public schools was the fact that the teachers were rotated between schools every 2-3 years. This did not happen at the private school, and it is not common practice even within the national programme in other states in Mexico. ${ }^{4}$ Analysing the interview data carefully, I realized the rotation of English teachers created an interesting dynamic because many had worked at different types of schools. This seemed to have its advantages and disadvantages. On the one hand, they explained that it took a while to build rapport and win the support of the regular classroom teacher, which was important to help them control the group, allow them to put posters on the wall, and even use the teacher's desk. On the other hand, it may have also ameliorated somewhat the differences we observed between lessons. Even taking into account the clear disparities detailed in the descriptions above, in the interviews the teachers expressed that they were conscious of how schools were different, but that they wanted to have the expectations and respect for their students regardless of their background.

There were also various examples across the dataset of teachers and lessons that clearly broke the mould and did not fit the general descriptions above. One teacher at a working-class school brought in papier-mâché television camera and microphone, turned one side of the classroom into a newsroom, and then had students re-enact an earthquake, a common occurrence in central Mexico (in order to have students practice the use of past and past progressive: When the earthquake happened, I was -ing). Another teacher started by greeting the class normally, but then suddenly dashed out and reappeared a minute later dressed in a cape and outfit to teach a lesson on superheroes (admittedly, a lesson on adjectives describing superheroes, but far and away from the best adjectives lesson I've ever seen). Likewise, some of the lessons in middle-class schools involved copying from the board into notebooks and decontextualized word lists, but such lessons were the exception rather than the rule as in the working-class schools.

At the affluent school, most of the teachers did not themselves belong to the upper-class. In their interviews, some teachers complained that the students were

4. Also, regular classroom teachers do not rotate because they have a different sort of contract. Although it is a national programme, because it is still relatively new and is administered by each state, the creation of stable positions based on equal contracts for English teachers has remained problematic. Most English teachers in both public and private schools are hourly wage workers with limited benefits. 
self-entitled and disrespectful in a way that even students from public school with discipline problems were not, and that the parents were pushy and difficult to deal with. Most of the teachers at the private school adopted mannerisms and language practices to fit in, but in one lesson, I observed a fourth-grade student openly mock her teacher who had inadvertently pronounced a word in Spanish in a way that marked her as from a rural or lower-class area. ${ }^{5}$

\section{The hidden curriculum of work, human capital theory, and neoliberalism}

The portraits of English lessons in three schools tell more than just the story of disparities of material resources across social class. The key difference is not merely that affluent children receive more hours of instruction and get to play with and explore prisms and the working-class children have to copy from the board ad nauseam; it is what the activities of exploring versus copying represent. Each embodies a different priority or principle of learning. The working-class students are surely learning something as they copy diligently, paying close attention to the mish-mashed vagaries of English spelling and of using coloured pens to differentiate their capital letters, just as the middle-class child who has created a PlayStation game poster, or the affluent child who studies the light refraction are learning particular things through the activities they engage in. As Anyon (1981) argues, each type of learning is preparing the child to fulfil her or his role in society and is structured by an invisible guiding principle which strongly influences the pedagogies in English language classrooms in ways that not only fulfil society's expectations for children of various class positions but also reproduces it. Bowles and Gintis (1976) term this the correspondence principle, the idea that schools maintain the social order by stabilizing and perpetuating existing class relations:

The educational system operates in this manner not so much through the conscious intentions of teachers and administrators in their day-to-day activities, but through a close correspondence between the social relationships which govern personal interaction in the work place and the social relationships of the educational system.

(pp.11-12)

5. In sociolinguistics, the tendency to mark one's speech and adopt manners of speaking to fit into a group is called convergent accommodation (McGroarty, 1996). The teacher, who had added a $[-\mathrm{s}]$ to the second person preterite verb conjugation ( $\dot{\mathrm{Ya} \text { terminastes}}$ ?) and thus marked herself as a rural or working-class speaker in Mexico, pretended not to hear the student and did not react. 
The practical concerns cited in the description above that teachers in workingclass schools have for not being able to do group work or needing to repeatedly reinforce basic vocabulary, therefore, become a rationale for fitting their teaching into the rung of the social order that the school occupies. Au and Apple (2009) argue that this formulation of the correspondence principle is overly deterministic, giving rise to too rigid neo-Marxist explanations of the role of class-based language differences that do not adequately account for human agency. However, while recognizing that teachers do have agency in developing their own pedagogical approach (such as the earthquake newsroom or superhero examples above), the portraits show the clear patterns that emerged within the English lessons and illuminate meaningful differences in underlying processes of teaching and learning in each classroom. Moreover, these differences seem to point to what Anyon (1980) refers to as the hidden curriculum of work:

the 'hidden curriculum' of schoolwork is tacit preparation for relating to the process of production in a particular way. Differing curricular, pedagogical, and pupil evaluation practices emphasize different cognitive and behavioural skills in each social setting and thus contribute to the development in the children of certain potential relationships to physical and symbolic capital, to authority, and to the process of work.

(pp. 89-9o)

In this line Sayer (2018) argues that English lessons in working-class schools emphasizing copying quickly and accurately, extreme repetition with attention to mundane details, and following procedures to complete work in an orderly, otherdirected manner, are preparing children to work in manual labour and service industry jobs, where these same skills will be valued. In almost all low-paying jobs in Mexico, English skills are not useful, but the mental stamina to do a monotonous task for hours on end certainly is, and the hidden curriculum of work in working-class English classrooms functions to inculcate this set of skills and dispositions. In some working-class schools in this study, teachers counter-balanced the hidden curriculum with communicatively oriented and student-centred activities. However, in many lessons, communicative skills were not seen as attainable or particularly relevant, whereas memorization of basic vocabulary was deemed important. Failure to be able to have children use English for real communicative purposes is rationalized by the need to keep recycling basic linguistic information to remediate their lack of foundational knowledge, and low student motivation attributed to the general lack of support from parents which limits children's opportunities to gain additional exposure to and practice with the language outside of school.

For middle-class children, the general pedagogical approach to teaching English should motivate students to want to learn the language. Active engage- 
ment and having fun are seen as important. Language learning is connected to using language for real-world purposes, and activities encourage students to figure out how to organize ideas, work collaboratively, understand concepts, present information to others and express preferences based on a range of options. Arguably, these same abilities will serve them in mid-level professional positions like those that their parents hold, where communication skills and guided decision-making and problem-solving are valued skills. Actual proficiency in English will likely be important as well, as it will allow them for instance, to pursue higher education, access information on-line for personal and professional purposes, and participate as global citizens in wider sociocultural practices. For affluent students, skills prioritized through English lessons build the symbolic capital of students. English is seen as a means for facilitating the learning of other forms of knowledge, and English is acquired by engaging in critical thinking and independent decision-making. The students are seen as emergent bilinguals, and their future use of English for professional purposes and the opportunities to travel abroad to interact with native speakers are assumed.

In each of the three cases, the degree of control the students are given over the content and manner of completing activities in English classrooms is comparable to the degree of control workers of the same social class standing have over the contents of their jobs. Bowles and Gintis (1976) posit that the maintenance of a differentiated education system responds not only to the demands of the labour market, but reproduces "legitimate inequality" which provides social stability: "schools play a dual role [in that they] increase surplus value (profit) by improving the productivity of workers through technical and social skills and appropriate motivations, and defuse and depoliticize social class relations [...] by foster[ing] legitimate inequality through the ostensibly meritocratic manner by which they reward and promote students, and allocate them to distinct positions with the occupational hierarchy" (p.11).

\section{The myth of opportunity: Human capital theory and early English programmes as neoliberal education policy}

The characterization of schools above suggests that increasing access to English for public school students does not, in and of itself, promote socioeconomic mobility. Mainly, this is because the teaching of English, like other subjects, inexorably comes to conform to the hidden curriculum of work. Pennycook (2007) refers to this generally as the "myth of international English" (p.90), or the misconception that widespread learning of English can help alleviate poverty. He cites newspaper articles touting the introduction of primary English teaching as 
the "key to a better life for the underprivileged" and challenges us to examine how access to English affects not just an individual's opportunities, but how it is related to broader social change, observing: "There is something rather bizarre in the belief that if everyone learned English, everyone would be better off" (p.102).

One obvious question is: why does the hidden curriculum operate as it does? The process of social reproduction described here seems to run counter to the commonly accepted narrative that English opens doors of opportunity for children across the socioeconomic spectrum, and that therefore having children in public schools start studying English earlier and achieve higher levels of English proficiency is a good thing for individuals, and that done on a large scale it can support a country's economic development. Wedell (2013) calls for a critical questioning of the "belief that citizens' proficiency in English will enhance the value of the national 'pool' of human capital, on which continued economic development [...] are thought to depend" (p.141). Human capital theory, proposed by Becker (1994), is simply put the idea that each individual generates a certain amount of productivity based on how relevant her skills are to the labour market. Economists, therefore, view education as an investment a society makes in an individual, which is worthwhile if it generates greater human capital, i.e. if it increases the individual's productivity in monetary terms beyond the cost of the investment for the labour market.

Tellingly, Wedell's comment, which is focused on sub-Saharan Africa, is mirrored by a report on the state of the Mexican education system commissioned by the government. After the disappointing results of the 2006 PISA Test (Program for International Student Assessment) that ranked Mexico at the bottom of the Organization for Economic Cooperation and Development (OECD) member countries, it sparked a debate about the education crisis. The report An Analysis of the Mexican School System in Light of PISA 2006 concluded that: "The Mexican education system is highly inefficient, incentives for improvement are weak and the quantity and quality of educational provision is well below OECD standards. In general, the Mexican education system needs to rapidly improve human capital development" (Hopkins, Ahtaridou, Matthews, \& Posner, 2007,p.4, emphasis added). Reyes Cruz et al. (2011) point out that this report was a strong impetus for the early English programme in Mexico, because (1) increasing English instruction is linked to developing human capital, and (2) adopting English programmes demonstrates that active steps are being taken to modernize the education system by bringing it in line with neoliberal economic policies (Sayer, 2015). Mechanisms such as PISA scores become a way for the OECD to apply pressures to governments to adopt neoliberal policies and programmes that promote institutions corporate capitalist interests (cf. the OECD website on "Labour markets, human 
capital and inequality," and topics of the OECD-International Monetary Fund (IMF)-World Bank June 2018 Conference on Structural Reforms (OECD, 2018)).

The workings of the hidden curriculum of English lessons in Mexico as evidenced in the micro, classroom-level pedagogical practices of teachers connect the early English programme to higher, macro-level neoliberal policies driven by considerations of developing human capital (Block et al., 2012). Flores (2013) argues that TESOL has largely been complicit with this trend, since the field has actively pushed the narrative of the necessity of global English and profited from its success: "TESOL in a neoliberal context has produced a new global market for English language teaching that has increased the profits of transnational corporations while reinforcing existing hierarchies between Anglo-American nations and the rest of the world's population" (p.501).

\section{Implications and conclusions: Educating language teachers as critical practitioners}

To summarize, the argument presented here is that English lessons in primary schools in Mexico are strongly socially stratified. Students are learning skills in English lessons, but they are not about acquiring L2 proficiency as a kind of neutral, linguistic knowledge. Instead, teachers' pedagogies are shaped by the hidden curriculum of work, which influences their lesson planning and decision-making in ways that make sense to the local context of their schools and classrooms, but ultimately lead them to inculcate in their students the skills and dispositions most closely associated with their social class position. The class-based practices of teaching and learning at the local level reflect broader neoliberal orientations towards educating workers with the requisite skills for the types of employment their parents have. For students at the higher end of the spectrum, classes are designed for acquiring advanced levels of English and are part-and-parcel with accessing information across subject areas, critical thinking and decision-making, creativity and problem-solving. For students from a working-class background, English lessons are only minimally oriented towards developing communicative skills, and more towards mastering procedures and developing mental stamina to perform repetitive tasks quickly and accurately. Whereas English is often now seen as a commodity, a skill which has value within the labour market (Heller, 2010; Seargeant, 2013), its value is only relative to the social and economic opportunities that individuals may already be able to access. The narrative that equates early English programmes with economic opportunities without addressing underlying educational processes fundamentally misconstrue the relation between language learning and social change. As Zentz (2016) states in Indonesia: 
"Beliefs that English alone will earn the Indonesian state and its citizens prosperous positions in national and global society act to conflate the English language with the other important material factors alongside which this symbol of wealth 'hitchhikes'” (p.433).

The main conclusion, therefore, is that for most students in Mexico, opportunities to develop actual proficiency in English are the result of greater socioeconomic prosperity, not the precursor to it. There are several implications of this finding for early English in public primary schools. The first is at a policy level. As Erling and Seargeant (2013) point out, research is needed to analyse the actual benefits of English programmes versus the costs of implementation, and make informed decisions about which types of programmes are best suited to a particular context, what age to start the programme, and how to structure the programme (e.g. English as a subject area versus English as a medium of instruction). Bruthiaux (2002) argues convincingly that in terms of economic development in poorer countries, quality L1 literacy programmes have a far greater effect on helping alleviate poverty than English programmes. We need to question the role English programmes have played as a symbol of the modernization and internationalization of curricula in developing countries. Instead, where increasing access to English instruction in public schools at early grades is undertaken, it should be implemented along with educational reforms that address other classbased disparities, such as class sizes, the digital divide in schools, access to books and materials, and teacher quality.

The second is at the level of teacher training. English teachers themselves, when confronted with the challenges of working with children in public schools across social class lines, need to be equipped to think about their own role in effecting change or perpetuating the status quo. López-Gopar (2016) provides a compelling description of a teacher preparation programme in Mexico organized as critical, project-based learning through which pre-service teachers developed teaching methodology that explored students' (and their own) identities through concepts such as colonialism and indigeneity.

Almost all of the teachers I interviewed for this study were optimistic about the programme and truly believed that teaching their students English could make a difference in their lives. At the same time, the excerpts in the portraits of three schools show how their understandings of what is guiding their lesson planning and classroom decision-making comes to be shaped by social pressures that they are largely unaware of. Jones and Vagle (2013) argue for training teachers for a "class-sensitive pedagogy" that helps them become practitioners able to reflect on how their own class position may differ from their students, and how the lived experiences of social class influence what they see as the possibilities for their students. I would extend this by arguing that teachers ought to think carefully 
through the underlying rationale for each type of activity they use. For example, what does copying actually accomplish? What if it were replaced with a dictation or similar sorts of tasks? While communicative language teaching methods, emphasizing highly interactive work in small groups, may not be realistic for many classrooms, it does not mean that elements and principles cannot be integrated that make lessons in working-class schools more engaging.

\section{References}

Anyon, J. (1981). Social class and social knowledge. Curriculum Inquiry, 11, 235-246. https://doi.org/10.1080/03626784.1981.11075261

Anyon, J. (1980). Social class and the hidden curriculum of work. The Journal of Education, 162(1), 67-92. https://doi.org/10.1177/002205748016200106

Au, W., \& Apple, M. (2009). Rethinking reproduction: Neo-Marxism in critical education theory. In M. Apple, W. Au, \& L.A. Gandin (Eds.), The Routledge international handbook of critical education (pp. 83-95). New York, NY: Routledge.

Bartlett, L., \& Vavrus, F. (2017). Rethinking case study research: A comparative approach. New York, NY: Routledge.

Becker, G. S. (1994). Human capital: A theoretical and empirical analysis with special reference to education (3rd ed.). Chicago, IL: University of Chicago Press.

Billings, S. (2014). Language, globalization and the making of a Tanzanian beauty queen. Bristol: Multilingual Matters.

Block, D. (2014). Social class in applied linguistics. New York, NY: Routledge.

Block, D., Gray, J., \& Holborow, M. (2012). Neoliberalism and applied linguistics. New York, NY: Routledge.

Bowles, S., \& Gintis, H. (1976). Schooling in capitalist America: Education reform and the contradictions of economic life. New York, NY: Basic Books.

Bruthiaux, P. (2002). Hold your courses: Language education, language choice, and economic development. TESOL Quarterly, 36(3), 275-296. https://doi.org/10.2307/3588414

Clayton, T. (2006). Language choice in a nation under transition: English language spread in Cambodia. New York, NY: Springer.

de Mejía, A.-M. (2009). Teaching English to young learners in Colombia: Policy, practice and challenges. Mextesol Journal, 33(1), 103-114.

de Mejía, A.-M. (2002). Power, prestige, and bilingualism: International perspectives on elite bilingual education. Clevedon: Multilingual Matters.

Enever, J. (2012). Current policy issues in early foreign language learning. CEPS Journal, 2(3), $9-26$.

Erling, E. J., \& Seargeant, P. (Eds.). (2013). English and development: Policy, pedagogy and globalization. Bristol: Multilingual Matters. https://doi.org/10.21832/9781847699473

Flores, N. (2013). The unexamined relationship between neoliberalism and plurilingualism: A cautionary tale. TESOL Quarterly, 47(3), 500-520. https://doi.org/10.1002/tesq.114

Forbes. (2014). ¿A cuál clase social pertences? [What social class do you belong to?]. Forbes México. May 17, 2014. Retrieved from: <https://www.forbes.com.mx/a-cual-clase-socialperteneces-segun-la-se/> (28 September, 2018). 
Hamid, M.O. (2010). Globalisation, English for everyone and English teacher capacity: Language policy discourses and realities in Bangladesh. Current Issues in Language Planning, 11(4), 289-310. https://doi.org/10.1080/14664208.2011.532621

Heller, M. (2010). The commodification of language. Annual Review of Anthropology, 39, 101-114. https://doi.org/10.1146/annurev.anthro.012809.104951

Hopkins, D., Ahtaridou, E., Matthews, P., \& Posner, C. (2007). An analysis of the Mexican school system in light of PISA 2006. London: London Centre for Leadership in Learning, University of London.

INEGI (Instituto Nacional de Estadística y Geografía [National Census Bureau of Mexico]). (2016). Encuesta Nacional de Ingresos y Gastos de los Hogares 2016. Retrieved from: <http://www.beta.inegi.org.mx/temas/hogares/> (30 April, 2018).

Jones, S., \& Vagle, M.D. (2013). Living contradictions and working for change: Toward a theory of social class-sensitive pedagogy. Educational Researcher, 42(3), 129-141. https://doi.org/10.3102/0013189X13481381

Kuchah, K. (2018). Early English medium instruction in Francophone Cameroon: The injustice of equal opportunity. System, 73(2), 37-47.

https://doi.org/10.1016/j.system.2017.10.001

López-Gopar, M. (2016). Decolonizing primary English language teaching. Bristol: Multilingual Matters. https://doi.org/10.21832/9781783095773

López-Gopar, M., \& Sughrua, W. (2014). Social class and English language education in Oaxaca, Mexico. Journal of Language, Identity \& Education, 13(2), 104-110. https://doi.org/10.1080/15348458.2014.901822

Matear, A. (2008). English language learning and education policy in Chile: Can English really open doors for all? Asia Pacific Journal of Education, 28(2), 131-147. https://doi.org/10.1080/02188790802036679

McGroarty, M. (1996). Language attitudes, motivation, and standards. In S. L. McKay \& N. Hornberger (Eds.), Sociolinguistics and language teaching (pp.3-46). Cambridge: Cambridge University Press.

Nguyen, H.T.M. (2011). Primary English language education policy in Vietnam: Insights from implementation. Current Issues in Language Planning, 12(2), 225-249. https://doi.org/10.1080/14664208.2011.597048

OECD (Organization for Economic Cooperation and Development). (2018). Agenda: 1st Joint IMF-OECD-World Bank Conference on Structural Reforms. Conference Program. Paris, France: June, 2018. Retrieved from: <http://www.oecd.org/eco/reform/joint-imf-wb-oecd -conf-structural-reform-2018/> (28 September, 2018).

Park, J.S., \& Wee, L. (2012). Markets of English: Linguistic capital and language policy in a globalizing world. New York, NY: Routledge.

Pennycook, A. (2007). The myth of English as an international language. In S. Makoni \& A. Pennycook (Eds.), Disinventing and reconstituting languages (pp. 90-115). Clevedon: Multilingual Matters.

Ramírez Romero, J.L., Sayer, P., \& Pamplón Irigoyen, E. N. (2014). English language teaching in public primary schools in Mexico: The practices and challenges of implementing a national language education program. International Journal of Qualitative Studies in Education, 27(8), 1020-1043. https://doi.org/10.1080/09518398.2014.924638 
Reyes Cruz, M., Murrieta Loyo, G., \& Hernández Méndez, E. (2011). Políticas lingüísticas nacionales e internacionales sobre la enseñanza del inglés en escuelas primarias. Revista Pueblos y Fronteras Digital, 6(12), 167-197. https://doi.org/10.22201/cimsur.18704115e.2011.12.126

Sayer, P. (2018). Does English really open doors? Social class and English teaching in public primary schools in Mexico. System, 73(2), 58-70. https://doi.org/10.1016/j.system.2017.11.006

Sayer, P. (2015). "More \& earlier”: Neoliberalism and primary English education in Mexican public schools. L2 Journal, 7(3), 40-56.

Sayer, P., \& López-Gopar, M. (2015). Language education in Mexico: Access, equity, and ideology. In W. Wright, O. García, \& S. Boun (Eds.), The handbook of bilingual and multilingual education, (pp. 576-589). Malden, MA: Wiley-Blackwell.

Seargeant, P. (2013). Introduction: English and development. In E. J. Erling \& P. Seargeant (Eds.), English and development: Policy, pedagogy and globalization (pp.1-20). Bristol, UK: Multilingual Matters. https://doi.org/10.21832/9781847699473-004

Tyack, D. \& Tobin, W. (1994). The 'grammar' of schooling: why has it been so hard to change? American Educational Research Journal, 31(3), 453-479.

Vavrus, F. (2002). Postcoloniality and English: Exploring language policy and the politics of development in Tanzania. TESOL Quarterly, 36(3), 373-397. https://doi.org/10.2307/3588418

Wedell, M. (2013). Proficiency in English as a key to development? Helping teachers to help learners succeed. In E. J. Erling \& P. Seargeant (Eds.), English and development: Policy, pedagogy and globalization (pp. 141-162). Bristol: Multilingual Matters. https://doi.org/10.21832/9781847699473-010

Wedell, M. (2008). Developing a capacity to make 'English for Everyone' worthwhile: Reconsidering outcomes and how to start achieving them. International Journal of Education Development, 28(6), 628-639. https://doi.org/10.1016/j.ijedudev.2007.08.002

Zentz, L. (2016). English on the rise: Access and resources in internationalization. In M. Gazzola \& B.-A. Wickström (Eds.), The economics of language policy (pp. 433-468). Cambridge, MA: The MIT Press.

\title{
Address for correspondence
}

\author{
Peter Sayer \\ The Ohio State University \\ 346A Arps Hall, 1945 N High St \\ Columbus, $\mathrm{OH} 43210$ \\ USA
}

Sayer.32@osu.edu 